\title{
Laboratorijski kazalniki anemije pri novorojenčku
}

\section{Laboratory Indices of Anaemia in the Neonate}

Petja Fister, Katerina Stojanov, Barbara Faganel Kotnik

\section{Izvleček}

Anemijo standardno laboratorijsko ugotavljamo kot zmanjšanje koncentracije hemoglobina in zmanjšanje števila eritrocitov in/ali hematokrita v volumski enoti krvi za več kot dva standardna odklona pod povprečno vrednostjo za starost.

Za ugotavljanje vzroka anemije in uspešno zdravljenje je pomembno poznavanje fiziologije eritropoeze ter normalnih vrednosti laboratorijskih kazalnikov pri donošenem in nedonošenem novorojenčku.

$\checkmark$ preglednem prispevku najprej opišemo fiziologijo eritropoeze in nato pojasnimo osnovne laboratorijske hematološke parametre. Sledi poglavje o manj pogostih laboratorijskih kazalnikih za vrednotenje aktivnosti kostnega mozga, ki bi jih lahko večkrat uporabljali v vsakdanji praksi in se tako izognili obširnemu jemanju krvi. Predstavljamo klinični pristop k novorojenčku $z$ anemijo. Zadnje poglavje posvečamo anemiji nedonošenčka, ki se $v$ mnogočem razlikuje od anemije donošenega novorojenčka.

Ključne besede: anemija, hemogram, eritropoetin, retikulocit, železo, novorojenček. 


\section{Uvod}

Anemija je zmanjšana oksiformna kapaciteta volumske enote krvi. S standardnimi laboratorijskimi preiskavami ugotavljamo zmanjšanje koncentracije hemoglobina in zmanjšanje števila eritrocitov in/ali hematokrita v volumski enoti krvi za več kot dva standardna odklona (SD) pod povprečno vrednost za otrokovo starost (1).

\section{Tvorba rdečih krvnih celic (eritropoeza) pri plodu in novorojenčku}

\section{Faze eritropoeze}

Primitivna eritropoeza poteka v prvih tednih nosečnosti v rumenjakovi vrečki. Nastajajo eritrociti s hemoglobini zarodka. Kasneje eritropoeza poteka v sinusoidih jeter pa tudi v vranici in bezgavkah, kar se povečuje do 5. meseca nosečnosti. Eritrociti vsebujejo hemoglobin ploda (fetalni hemoglobin, HbF). Po 5. mesecu nosečnosti hematopoeza v kostnem mozgu (medularna hematopoeza) pri plodu strmo narašča $(2,3)$. Nastajajo tudi eritrociti $z$ vrsto hemoglobina, ki prevladuje pri odraslem človeku (adultni hemoglobin, $\mathrm{HbA}$ ).

$\checkmark$ kostnem mozgu so pronormoblasti najbolj zgodnja oblika celic rdeče vrste. Z njihovim zorenjem nastanejo bazofilni, polikromatofilni in acidofilni normoblasti, imenovani tudi eritroblasti. Med dozorevanjem eritroblastov pride do zmanjševanja velikosti celic, izgube jedra, spremembe razmerja med jedrom in citoplazmo ter zgoščevanja kromatina v grude. Citoplazma postaja zaradi sinteze hemoglobina bolj acidofilna. Ob izgubi jedra nastanejo retikulociti, ki so večji kot eritrociti in še vedno vsebujejo segmente RNK. Retikulociti še nekaj časa ostanejo v kostnem mozgu, nato se izplavljajo v kri, kjer v približno 24 urah izgubijo RNK in dozorijo $v$ zrele eritrocite. Zrel eritrocit pri odraslem preživi v krvnem obtoku približno 120 dni. Makrofagi vranice, jeter in kostnega mozga dnevno odstranijo povprečno $0,8 \%$ vseh eritrocitov (4-7).

\section{Eritropoetin}

Eritropoezo spodbuja hematopoetski rastni dejavnik hormon eritropoetin (EPO). Gen za EPO se nahaja na sredini dolgega kraka 7. kromosoma (q22). Glede na zaporedje nukleotidov $\checkmark$ CDNK se EPO ploda ne razlikuje od EPO v odraslosti $(7,8)$. Kemijsko je EPO sialoglikoprotein z molekulsko maso 35-39 kD. Najbolj pomemben del molekule je polipeptidna veriga 166 aminokislin, ki se veže na receptorje na tarčni celici. Zaradi velikosti molekule materin EPO ne prehaja posteljice. Koncentracija se $v$ nosečnosti pri plodu postopno povečuje. Nastaja večinoma $v$ jetrih, ki so med nosečnostjo v pogojih sorazmernega pomanjkanja kisika, saj večina s kisikom bogate krvi obide jetra in teče iz posteljice preko popkovnične vene in venskega voda naravnost $v$ srce. Ker pa je občutljivost jeter za kisik manjša, je ob tem majhno tudi tvorjenje EPO in policitemija se pri plodu ne razvije. $V$ zadnjih tednih nosečnosti se prične EPO tvoriti v plodovih ledvicah, ki so bolj občutljive na hipoksijo, po rojstvu pa se ga večina sintetizira v celicah peritubularnega intersticija ledvične skorje, manj kot petina pa ga nastane $v$ perivenskih hepatocitih in Kupferjevih celicah jeter ter $v$ makrofagih (9).

Povišane koncentracije EPO pri plodu ali v amnijski tekočini lahko pomenijo hipoksijo ploda. EPO, ki se izloča kot odgovor na hipoksijo, po krvi potuje do eritroblastov v kostnem mozgu, kjer se veže na specifične receptorje in s tem omogoči njihovo delitev in zorenje (7). Normalna koncentracija EPO ob rojstvu je $5-100 \mathrm{mU} / \mathrm{ml}$.

\section{Hemoglobin}

Hemoglobin veže molekule kisika (oksiformna kapaciteta eritrocita) in ga oddaja tkivom ter odstranjuje ogljikov dioksid iz tkiv. Hemoglobin je tetramer, zgrajen iz dveh parov polipeptidnih verig globina alfa in dveh nealfa verig beta $(\beta)$, gama $(\gamma)$, delta $(\delta)$, zeta $(\zeta)$ ali epsilon $(\varepsilon)$. Verigi epsilon in zeta sta prisotni samo $v$ hemoglobinih zarodka: hemoglobin Gower 1 $(\varepsilon 4)$, Gower $2(a 2, \varepsilon 2)$ in Portland ( $\zeta 2$, y2). Fetalni hemoglobin (HbF; a2, y2) je glavna vrsta hemoglobina v poznem fetalnem obdobju in ob rojstvu. $\mathrm{Ob}$ rojstvu je delež HbF približno $75 \%$, delež ostalega predstavlja $\mathrm{HbA}$ (a2, $\beta 2$ ). Do četrtega meseca starosti je delež $\mathrm{HbF}$ le še $20 \%$, do prvega leta pa manj kot $2 \%$. Glavna vrsta hemoglobina pri odraslih je hemoglobin A (več kot $95 \%$ ), približno 2-3 \% je HbA2 (a2, $\delta 2), \mathrm{Hb} F$ pa je običajno približno $2 \%$.

Vsaka veriga globina ima $v$ terciarni zgradbi hidrofobni žep, kjer je vezana prostetična skupina, imenovana hem. Hem je sestavljen iz protoporfirina, $v$ katerem je vezan atom dvovalentnega železa ( $\mathrm{Fe}$ ). V kvarterni zgradbi hemoglobina razlikujemo dve vrsti stičnih predelov med globinskimi verigami: prvi poveže elektrostatične sile verig $a$ in $\beta v$ dimer $\alpha-\beta$, kar omogoča stabilnost tetramera; pri drugem pride v času vezave ali sproščanja kisika do rotacije enega dimera proti drugemu (interakcija hem-hem). Sledi sprememba afinitete za kisik in disociacijska krivulja za oksihemoglobin ima zato sigmoidno obliko $(7,10-14)$.

\section{Ocena zalog železa v telesu}

$\checkmark$ telesu se $70 \%$ železa $(\mathrm{Fe})$ nahaja v hemoglobinu. Ostalo Fe je v obliki feritina ali hemosiderina $v$ retikuloendotelnih celicah, jetrnih celicah in celicah skeletnih mišic. V klinični praksi ocenjujemo zaloge Fe $z$ določanjem koncentracije $\mathrm{Fe}$, nasičenostjo transferina in koncentracijo feritina v serumu. Raven transferina $v$ krvi se podobno kot raven albumina pri vnetju zniža, zato lahko izmerimo lažno nižje vrednosti. Vrednost feritina je pri vnetjih in malignomih zvišana, kar moramo upo- 


\begin{tabular}{|c|c|c|c|c|c|c|c|}
\hline Starost & Hemoglobin $(g / l)$ & Hematokrit (\%) & Eritrociti (mm3) & $\operatorname{MCV}(f \mathrm{l})$ & $\mathrm{MCH}(\mathrm{pg})$ & $\mathrm{MCHC}(\mathrm{g} / \mathrm{dl})$ & Retikulociti (\%) \\
\hline popkovnična kri & 16,8 & 53,0 & 5,25 & 107 & 34 & 317 & $3-7$ \\
\hline 1 dan & 18,4 & 58,0 & 5,8 & 108 & 35 & 325 & $3-7$ \\
\hline $3 \mathrm{dni}$ & 17,8 & 55,0 & 5,6 & 99.0 & 33 & 330 & $1-3$ \\
\hline $7 \mathrm{dni}$ & 17,0 & 54,0 & 5,2 & 98.0 & 32,5 & 330 & $0-1$ \\
\hline 2 tedna & $16,6 \pm 0,11$ & $53 \pm 0,4$ & $4,9 \pm 0,03$ & $105,3 \pm 0,6$ & $33,6 \pm 0,1$ & $314 \pm 1,1$ & $0,8 \pm 0,6$ \\
\hline $1 \mathrm{mesec}$ & $13,9 \pm 0,10$ & $44 \pm 0,3$ & $4,3 \pm 0,03$ & $101,3 \pm 0,3$ & $32,5 \pm 0,1$ & $318 \pm 1,2$ & $0,9 \pm 0,8$ \\
\hline 2 meseca & $11,2 \pm 0,06$ & $35 \pm 0,2$ & $3,7 \pm 0,02$ & $94,8 \pm 0,3$ & $30,4 \pm 0,1$ & $318 \pm 1,1$ & $1,8 \pm 1,0$ \\
\hline 4 mesece & $12,2 \pm 0,14$ & $38 \pm 0,4$ & $4,3 \pm 0,06$ & $86,7 \pm 0,8$ & $28,6 \pm 0,2$ & $327 \pm 2,7$ & \\
\hline 6 mesecev & $12,6 \pm 0,10$ & $36 \pm 0,3$ & $4,7 \pm 0,05$ & $76,3 \pm 0,6$ & $26,8 \pm 0,2$ & $350 \pm 1,7$ & \\
\hline 9 mesecev & $12,7 \pm 0,09$ & $36 \pm 0,3$ & $4,7 \pm 0,04$ & $77,7 \pm 0,5$ & $27,3 \pm 0,2$ & $349 \pm 1,6$ & \\
\hline 12 mesecev & $12,7 \pm 0,09$ & $37 \pm 0,3$ & $4,7 \pm 0,04$ & $77,5 \pm 0,5$ & $26,8 \pm 0,2$ & $343 \pm 1,5$ & \\
\hline
\end{tabular}

TABELA 1. REFERENČNE HEMATOLOŠKE VREDNOSTI V PRVEM LETU ŽIVLJENJA PRI ZDRAVIH DONOŠENIH OTROCIH (17)
TABLE 1. HAEMATOLOGICAL REFERENCE VALUES IN THE FIRST YEAR OF LIFE IN HEALTHY FULL-TERM CHILDREN (17). števati pri tolmačenju izvida. Tako v krvi izmerimo neustrezno nizko raven serumskega Fe in transferina ter visoko raven serumskega feritina $(15,16)$.

\section{Absolutno in funkcionalno pomanjkanje železa v organizmu}

O absolutnem pomanjkanju železa govorimo takrat, ko so zaloge železa v organizmu zmanjšane ali povsem izčrpane. Koncentracije Fe, transferina in feritina v serumu so znižane sorazmerno s pomanjkanjem.

Funkcionalno pomanjkanje Fe je stanje povečane potrebe po Fe ob zmanjšani razpoložljivosti $\mathrm{Fe}$, kljub zadostnim ali celo povečanim zalogam. Tako stanje se lahko pojavi pri zdravljenju z rekombinantnim humanim EPO, ki močno pospeši eritropoezo ob prepočasnem sproščanju Fe iz zalog (16), ter pri kroničnh vnetjih, novotvorbah in pri avtoimunskih boleznih, pri katerih je sproščanje Fe iz zalog ovirano.

S standardno analizo hemograma in s pomočjo sodobnih analizatorjev ugotovimo laboratorijske kazalnike eritrocitov, kot so število eritrocitov, vrednost hematokrita, oblika in velikost eritrocita, širina razporeditve eritrocitov glede na velikost, delež hipokromnih eritrocitov, koncentracija hemoglobina, koncentracija hemoglobina $v$ eritrocitih, količina hemoglobina $v$ eritrocitih in laboratorijski kazalniki retikulocitov (Tabela 1) (17).

\section{Laboratorijski kazalniki eritrocitov}

Pri plodu se število eritrocitov, vrednost hematokrita in koncentracija hemoglobina postopno povečujejo.

Eritrociti so pri novorojenčku po velikosti in obliki zelo različni. V hemogramu najdemo tarčne celice, akantocite, pikčaste eritrocite, stomatocite in siderocite. Deformiranost membrane eritrocita je odvisna od razmerja med površino in volumnom eritrocita, viskoznosti citoplazme in togosti membrane. Deformiranost membrane eritrocita vpliva na življenjsko dobo eritrocita. Eritrociti donošenega novorojenčka imajo življenjsko dobo 45-80 dni, nedonošenčka pa 35-50 dni (18).

Vrednost hematokrita je pri plodu v drugem trimesečju med 0,30 in 0,40, pri donošenem novorojenčku pa med 0,50 in 0,63 . Na vrednost hematokrita vplivata čas prekinitve popkovine in mesto jemanja krvi; kapilarni hematokrit je višji od venskega in arterijskega.

Povprečna koncentracija hemoglobina je pri plodu v desetem tednu nosečnosti $90 \mathrm{~g} / \mathrm{l}$, pri donošenem novorojenčku pa 160-170 g/l. Nekaj ur po rojstvu se koncentracija hemoglobina zaradi zmanjšanja volumna plazme še poveča. $V$ naslednjih dneh se koncentracija hemoglobina začne zmanjševati, ker zaradi boljše oksigenacije krvi in tkiv v pogojih zunajmaterničnega okolja pride do hitrega znižanja koncentracije EPO in prehodne supresije eritropoeze. K zmanjševanju koncentracije hemoglobina prispevajo še krajša življenjska doba eritrocitov, hitro pridobivanje telesne teže in povečanje količine plazme. Nastajanje eritrocitov ne sledi sorazmerno, kar dodatno privede do razredčenja krvi in do pojava t. i. fiziološke anemije.

Velikost eritrocita (MCV) se postopno zmanjšuje. Pri zarodku je vrednost MCV $180 \mathrm{fl}$, v sredini nosečnosti 130-140 fl, ob donošenem novorojenčku $115 \mathrm{fl}$. Nižjo vrednost MCV imajo novorojenčki ob rojstvu s talasemijo a minor in dedno sferocitozo. Manj pogos- 


\begin{tabular}{|c|c|c|c|c|c|c|c|c|}
\hline $\begin{array}{l}\text { Nosečnostna } \\
\text { starost }\end{array}$ & $\begin{array}{r}\text { Število } \\
\text { novorojenčkov }\end{array}$ & $\begin{array}{r}2,5 . \\
\text { percentil }\end{array}$ & $\begin{array}{r}10 . \\
\text { percentil }\end{array}$ & $\begin{array}{r}25 . \\
\text { percentil }\end{array}$ & $\begin{array}{r}50 . \\
\text { percentil }\end{array}$ & $\begin{array}{r}75 . \\
\text { percentil }\end{array}$ & $\begin{array}{r}90 . \\
\text { percentil }\end{array}$ & $\begin{array}{r}97,5 . \\
\text { percentil }\end{array}$ \\
\hline $24-29$ & 55 & 21,1 & 27,2 & 29,0 & 31,2 & 32,6 & 33,5 & 36,8 \\
\hline $30-36$ & 241 & 25,1 & 27,9 & 29,7 & 31,4 & 32,9 & 34,2 & 36,1 \\
\hline $37-42$ & 216 & 25,5 & 27,3 & 29,9 & 32,4 & 34,4 & 35,8 & 37,6 \\
\hline $24-42$ & 512 & 25,2 & 27,5 & 29,8 & 31,7 & 33,5 & 35,2 & 37,0 \\
\hline
\end{tabular}

TABELA 2. REFERENČNE VREDNOSTI KOLIČINE HEMOGLOBINA V RETIKULOCITIH (RET-HE) V PG/L V PRVIH DNEVIH PO ROJSTVU (PEDIATRIČNA KLINIKA TUBINGEN, NEMČIJA) (25).
TABLE 2. REFERENCE VALUES OF THE AMOUNT OF HAEMOGLOBIN IN RETICULOCYTES (RET-HE) IN PG/L IN THE FIRST DAYS AFTER BIRTH (PAEDIATRIC CLINIC TUBINGEN, GERMANY) (25). to je nizka vrednost MCV posledica pomanjkanja železa pri plodu, lahko pa je posledica kronične fetomaternalne krvavitve ali krvavitve dvojčka v dvojčka. MCV se pri nedonošenih novorojenčkih po rojstvu zelo hitro zmanjšuje in je bolj povezana s kronološko kot pa s postkoncepcijsko starostjo.

Koncentracija hemoglobina v eritrocitu (MCHC) ostaja pretežno nespremenjena od vrednosti pri plodu po 32. tednu nosečnosti do odraslosti (315-345 g/l). Ko se površina eritrocita zmanjša in se hemoglobin stisne $v$ manjšem prostoru, se MCHC poveča (dedna sferocitoza, hemolitična bolezen novorojenčka zaradi neskladja $A B 0$, mikroangiopatska hemolitična anemija).

Vrednost hemoglobina $v$ eritrocitu $(\mathrm{MCH})$ odseva povprečno količino hemoglobina $v$ eritrocitu in je ob rojstvu 34-36 pg, kasneje pa se znižuje $(19,20)$.

Širina razporeditve eritrocitov (RDW). Čim večje so razlike v velikosti posameznih eritrocitov, širša je RDW. Ker so nezreli eritrociti večji od zrelih in starih, ima novorojenček z aktivno eritropoezo povišano vrednost RDW (21). Referenčne vrednosti RDW v popkovni krvi so $11,4-21,5 \%$.
Določanje deleža hipokromnih eritrocitov s koncentracijo hemoglobina $(\mathrm{MCHC})<280 \mathrm{~g} / \mathrm{l}$ (\% HYPO-Eri) in deleža hipokromnih eritrocitov z vsebnostjo hemoglobina $(\mathrm{MCH})<17$ pg (Hypo-He). Ta dva parametra služita za oceno pomanjkanja Fe v zadnjih 3 mesecih. Parametrov \% HYPO-Eri in Hypo-He med seboj ne moremo neposredno primerjati zaradi razlik v načinu določanja. Lahko pa primerjamo računsko pretvorjene vrednosti. Vrednost \% HYPO-Eri pri zdravih odraslih je $<2,5 \%(16,22)$. Hipokromni eritrociti se pojavijo pri absolutnem in funkcionalnem pomanjkanju železa v telesu.

\section{Laboratorijski kazalniki retikulocitov - vrednotenje trenutne aktivnosti kostnega mozga}

Število in delež retikulocitov. Retikulociti imajo življensko dobo samo 18-36 ur, zato so dober kazalnik trenutnega stanja eritropoeze v kostnem mozgu. Pri plodu sta število in delež retikulocitov takoj po rojstvu višja kot kadar koli kasneje v življenju, ker je koncentracija EPO relativno visoka. Takoj po rojstvu imajo donošeni novo- rojenčki $150.000-400.000$ retikuloci-

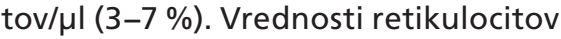
pri nedonošenih novorojenčkih so še višje (6-10\%). Po rojstvu se nastajanje EPO upočasni in delež retikulocitov se po enem tednu zmanjša na $1 \%$. Vrednosti retikulocitov se ponovno povečajo ob pospešeni eritropoezi (23). Vrednosti v območju 0,5-2 \% kažejo na to, da je nastajanje eritrocitov normalno $(15,22)$.

Delež nezrelih retikulocitov (IRF) je razmerje med mladimi nezrelimi retikulociti in celotnim številom retikulocitov in je zgodnji kazalnik ocene aktivnosti eritropoeze. Normalna vrednost IRF pri odraslih je 19,1-28,9 \% (22). Povišane vrednosti so znak povečane eritropoeze. Vrednost IRF se poveča že nekaj ur po začetku anemije, medtem ko absolutno število retikulocitov naraste šele po 2-3 dneh. Nedonošenčki z nosečnostno starostjo 34.-36. tednov so imeli IRF pri dveh tednih $29 \%$, pri treh mesecih pa $13 \%$, z nosečnostno starostjo med 32.-34. tedni pri dveh tednih $22 \%$, pri treh mesecih pa $12 \%$. IRF se je $v$ obeh skupinah nedonošenčkov znižal s $36,2 \pm 5,6 \%$ ob rojstvu na $10 \pm$ $4,9 \%$ pri treh mesecih. Iz raziskave so bili izključeni nedonošenčki z anemijo in nedonošenčki, zdravljeni s transfuzijo koncentriranih eritrocitov (24). 
Koncentracija hemoglobina v retikulocitih $(\mathrm{CHr})$ in izračunana vrednost ekvivalenta hemoglobina $v$ retikulocitih (RET-He) sta občutljiva zgodnja kazalnika funkcionalnega pomanjkanja železa v kostnem mozgu. Ker je življenjska doba retikulocitov v krvi le 1-2 dni, $\mathrm{CHr}$ in RET-He dajeta oceno trenutne eritoropoezne aktivnosti v kostnem mozgu in sta boljša napovedna dejavnika za oceno pomanjkanja železa v primerjavi $z$ biokemijskimi in klasičnimi eritrocitnimi parametri. $V$ raziskavah so potrdili linearno ujemanje parametrov $\mathrm{CHr}$ in Ret-He. Referenčne vrednosti $\mathrm{CHr}$ so 30-36 pg/l, RET-He pa 23,9-30,9 pg. Po podatkih ameriške raziskave je $\mathrm{CHr}$ ob rojstvu 30,3 $\pm 1,1 \mathrm{pg} / \mathrm{l}, 4$. dan $28,4 \pm 0,5$ $\mathrm{pg} / \mathrm{l}$, pri treh mesecih pa $28 \mathrm{pg} / \mathrm{l}$ (Tabela 2) (25).

\section{Anemija pri novorojenčku}

Najnižja koncentracija hemoglobina (redko < $90 \mathrm{~g} / \mathrm{l}$ (povprečna $112 \mathrm{~g} / \mathrm{l})$ ) se pri donošenih novorojenčkih pojavi v starosti 4-8 tednov in jo imenujemo fiziološka anemija.

Povprečne dnevne potrebe Fe pri zdravem novorojenčku in dojenčku do 6 . meseca starosti so $0,27 \mathrm{mg} / \mathrm{dan}$, pri dojenčku od 7. do 12. meseca $11 \mathrm{mg} /$ dan, pri otroku od 1. do 3. leta $7 \mathrm{mg} /$ dan in od 4 . do 8 . leta $10 \mathrm{mg} / \mathrm{dan}$. Materino in kravje mleko vsebujeta $0,35 \mathrm{mg}$ železa na liter oz. manj kot 1,5 mg/1000 kalorij, razlikujeta pa se $v$ deležu absorpcije zaužitega železa. Materino mleko je biorazpoložljivo v $40-100 \%(26,27)$. Iz materinega mleka se povprečno absorbira nekoliko več kot $50 \%$ železa, iz kravjega pa le $4-10 \%(3)$.

Pomanjkanje železa pri plodu in novorojenčku predstavlja tveganje za motnje $v$ normalnem razvoju možganov, saj je železo sestavni del številnih encimov in beljakovin ter sodeluje $v$ procesih mielinizacije, dendritogeneze, sinaptogeneze in prenosa impulzov med nevroni. Pomanjkanje železa je pri donošenih novorojenčkih bolj poveza- no s slabšim kognitivnim razvojem, pri nedonošenih pa s slabšim motoričnim razvojem $(28,29)$.

Zdravljenje anemije je odvisno od vzroka anemije in od stopnje anemije.

Če kazalniki vrednotenja anemije in aktivnosti kostnega mozga pri novorojenčku kažejo na pomanjkanje $\mathrm{Fe}$, se odločimo za dajanje Fe v odmerku 3-5 mg elementarnega železa/kgTT, lahko ga pa dajemo tudi v odmerku približno $1 \mathrm{mg} / \mathrm{kg} / \mathrm{TT}$ (največ $15 \mathrm{mg} / \mathrm{dan}$ ) že kmalu po rojstvu. Odvisno od vrste posameznega pripravka ga razdelimo na dva ali tri odmerke dnevno. Vsrka se ga le približno $10 \%$.

Železo nadomeščamo s peroralnimi pripravki železa v obliki sirupov ali kapljic, izjemoma parenteralno (14). Peroralno nadomeščanje Fe je tudi najbolj učinkovito. Bolje se absorbira železo v dvovalentni obliki (npr. ferosulfat, feroglukonat, ferolaktat, feroglicinsulfat). Da se železo v trivalentni obliki lažje absorbira, mora biti vezano v poseben kompleks (14). Že 12-24 ur po začetku zdravljenja lahko ugotavljamo subjektivno izboljšanje počutja, manjšo razdražljivost in boljši tek. Po preteku 3-4 dni nastopi eritroidna hiperplazija v kostnem mozgu, po 4-5 dneh pa v periferni krvi zaznamo retikulocitni odgovor, ki je najvišji 5-10 dni po pričetku zdravljenja. Po 4-30 dneh se prične zviševati koncentracija hemoglobina s hitrostjo 0,25-0,4 g/dl/ dan, nato pa s hitrostjo 0,1-0,15 g/dl/ dan. Po doseženi normalizaciji koncentracije hemoglobina in vrednosti MCV nadaljujemo z zdravljenjem še 6-8 tednov, da zapolnimo zaloge železa v telesu.

Neželeni učinki peroralnega dajanja železa so lahko prebavne motnje (slabost, bruhanje, epigastrične bolečine, zaprtje in driska). Pogostost težav je odvisna od količine ioniziranega Fe v želodcu in dvanajstniku $(3,19,20)$. Omenjene neželene učinke lahko v večini primerov premostimo z ustreznimi ukrepi ali zamenjavo farmacevtske oblike peroralnega zdravila.
Učinkovitost in varnost parenteralnega dajanja Fe pri otrocih do drugega leta starosti ni dovolj raziskana. Ob nekaterih neželenih učinkih peroralnega odmerjanja $\mathrm{Fe}$ in pri redkih drugih indikacijah dajemo Fe parenteralno v odmerku 3 mg Fe/kg telesne teže enkrat na teden ali enkrat na dva tedna v počasni intravenski infuziji (30). Pričakovan porast koncentracije hemoglobina je $20 \mathrm{~g} / \mathrm{l}$ v treh tednih po začetku zdravljenja (14). Neželeni učinki parenteralnega dajanja železa so lahko flebotromboza, rdečina obraza, glavobol, vročina, bruhanje, bolečine v trebuhu ali težko dihanje (14).

Hudo in nenadno izgubo krvi zdravimo s transfuzijo koncentriranih filtriranih obsevanih eritrocitov ustrezne krvne skupine CMV-negativnega dajalca. Transfuzijsko zdravljenje lahko za dalj časa zakrije možnosti nadaljnjega diagnosticiranja vzrokov slabokrvnosti, zato moramo še pred transfuzijskim zdravljenjem izpeljati vse diagnostične ukrepe, ki jih dopušča bolnikovo klinično stanje. Transfuzija koncentriranih eritrocitov lahko povzroči postransfuzijsko reakcijo, zavrnitveno reakcijo in preobremenitev s tekočinami. Anemija se nekaj tednov po transfuziji pogosto ponovi, ker s transfuzijo novorojenček prejme odrasli tip hemoglobina z zmanjšano afiniteto za kisik, kar zavre izločanje EPO.

Novorojenčki s hudo obliko hemolitične bolezni in nedonošenčki za preprečevanje anemije prejmejo rekombinantni humani EPO (epoetin a $B$, darbapoetin a) v obliki podkožnih injekcij v odmerku 50-1200 IE/kg tedensko, razdeljenega $v$ treh odmerkih. Potrebno je dodajati Fe, občasno tudi folno kislino in vitamin $E(7,30,31)$.

\section{Posebnosti anemije pri nedonošenčku}

Nedonošenčki in zahirančki imajo v prvih šestih mesecih življenja večje tveganje sideropenične anemije kot 


\begin{tabular}{lrrrrr} 
Starost & Eri $(10 \times 12 / \mathrm{l})$ & $\begin{array}{r}\text { Hemoglobin } \\
(\mathrm{g} / \mathrm{dl})\end{array}$ & $\mathrm{MCV}(\mathrm{fl})$ & $\mathrm{MCH}(\mathrm{pg})$ & $\mathrm{MCHC}(\mathrm{g} / \mathrm{l})$ \\
\hline $1 \mathrm{dan}$ & $4,71 \pm 0,75$ & $18,2 \pm 2,7$ & $115 \pm 5$ & $38,9 \pm 1,7$ & $33,5 \pm 1,2$ \\
\hline $3 \mathrm{dni}$ & $4,4 \pm 0,83$ & $16.2 \pm 2.9$ & $112 \pm 4$ & $39,0 \pm 3,4$ & $33,8 \pm 1$ \\
\hline $7 \mathrm{dni}$ & $4,45 \pm 0,83$ & $16.3 \pm 2.9$ & $110 \pm 5$ & $37,3 \pm 1,8$ & $33,9 \pm 1,3$ \\
\hline $14 \mathrm{dni}$ & $4,10 \pm 0,69$ & $14.5 \pm 2.4$ & $106 \pm 5$ & $36,3 \pm 1,9$ & $33.9 \pm 1$ \\
\hline $21 \mathrm{dni}$ & $3,71 \pm 0,59$ & $12.9 \pm 2$ & $102 \pm 5$ & $35,3 \pm 2,2$ & $34.2 \pm 1.1$ \\
\hline $28 \mathrm{dni}$ & $3,17 \pm 0,6$ & $10,9 \pm 1,9$ & $100 \pm 5$ & $35,1 \pm 1,9$ & $34,4 \pm 1,0$ \\
\hline $35 \mathrm{dni}$ & $2,97 \pm 0,45$ & $10 \pm 1.4$ & $98 \pm 5$ & $34,4 \pm 1,5$ & $34,5 \pm 0,7$ \\
\hline $42 \mathrm{dni}$ & $2,94 \pm 0,49$ & $9.5 \pm 1.5$ & $97 \pm 5$ & $32,2 \pm 1,7$ & $33,7 \pm 0,9$ \\
\hline $49 \mathrm{dni}$ & $3,21 \pm 0,59$ & $10.1 \pm 1,7$ & $95 \pm 5$ & $32,1 \pm 1,6$ & $33,5 \pm 1$ \\
\hline
\end{tabular}

TABELA 3. VREDNOSTI RDEČE KRVNE VRSTE PRI NEDONOŠENIH NOVOROJENČKIH (32).

TABLE 3. RED BLOOD CELL REFERENCE VALUES IN PRETERM NEWBORNS (32).

donošeni. Fiziološko zmanjšanje hemoglobina se pri nedonošenčkih pojavi že po dopolnjenem prvem tednu življenja, do najnižje vrednosti (70-90 $\mathrm{g} / \mathrm{l})$ pa pride v starosti 6 tednov, oziroma 2-6 tednov prej kot pri donošenih novorojenčkih (Tabela 3) (32). Te spremembe $v$ koncentraciji hemoglobina niso posledica pomanjkljive prehrane ali bolezni in nedonošenček zaradi njih nima nikakršnih težav. Če so nedonošenčki zdravljeni v enotah intenzivne medicine, k zmanjšanju koncentracije hemoglobina prispeva tudi jemanje krvi za laboratorijske preiskave.

Nefiziološka (poglobljena) anemija nedonošenčka se pojavi 4-12 tednov po rojstvu, predvsem pri nedonošenčkih z zelo nizko porodno težo. Je posledica nižje stopnje eritropoeze $v$ kostnem mozgu s posledično nižjim deležem retikulocitov v periferni krvi $(<3 \%)$. Anemija je normocitna normokromna. Koncentracija hemoglobina je $<70-100 \mathrm{~g} / \mathrm{l}$, hematokrita $\leq 0,30$, otrok ima tudi klinične znake slabokrvnosti. Vrednosti levkocitov in trombocitov so normalne.

Ključni dejavnik v nastanku nefiziološke anemije nedonošenčkov je nezadostno izločanje EPO. Zaradi premajhne občutljivosti jeter na hipoksijo tvorba EPO $v$ jetrih ne zadostuje za zunajma- ternično življenje. Celice ledvičnega intersticija so še nezrele in sinteza EPO ne zmore zadostiti potrebam organizma. Številni vnetni posredniki, IL-1, TNF in zdravila motijo delovanje EPO in dodatno zavirajo eritropoezo $(7,31)$.

Anemijo nedonošenčkov, ki niso prejeli transfuzije eritrocitov, preprečujemo s pripravkom železa v odmerku 2-4 mg/kg TT v obdobju stabilne rasti $s$ pričetkom med 4 . in 8 . tednom življenja in vse do 12.-15. meseca starosti. Lahko pa predpišemo odmerek $1 \mathrm{mg} /$ kg TT že od zgodnjega neonatalnega obdobja naprej. V raziskavi so ugotovili, da so pri $15 \%$ nedonošenčkov z zelo nizko porodno težo kljub nadomeščanju železa v višjih odmerkih (4-6 mg/ $\mathrm{kg} / \mathrm{TT}$ ) v starosti 2 mesecev ugotavljali pomanjkanje železa (29).

Sideropenično anemijo razvije v prvem letu življenja 25-85 \% nedonošenčkov. Dejavniki tveganja za razvoj sideropenične anemije pri nedonošenčku so anemija, hipertenzija in kajenje matere. $\mathrm{Z}$ raziskavo, ki je spremljala nedonošene otroke, ki so prejemali pripravek železa od 2. tedna dalje, so ugotovljali manj blagih motoričnih odstopov (širokotirna hoja, disdiadohokinezija, dismetrija) in boljši kognitivni izid v starosti 5 let. Dolgoročnih učinkov dajanja železa na rast in razvoj ne poznamo (29).
Posledice pomanjkanja železa pri nedonošenčkih z zelo nizko porodno težo so slabše pridobivanje telesne teže, motnje $v$ delovanju ščitnice ( $F e$ je ključnega pomena za delovanje encima tiroidna peroksidaza (34)), zmanjšana imunost, temperaturna nestabilnost in neoptimalen razvoj možganov (28). Do zmanjšane imunosti pri anemiji zaradi pomanjkanja železa pride zaradi okrnjene granulopoeze, ki povzroči nevtropenijo. Dokazali so, da rekombinantni EPO zmanjša odzivnost prekurzorskih celic na granulocitne kolonije stimulirajoči dejavnik (G-CSF). Najverjetneje je učinek endogenega EPO, ki se iz ledvic sprošča pri anemiji, podoben (33). Pomanjkanje železa v prehrani v zgodnjem otroštvu je povezano s poznimi nevrološko-razvojnimi motnjami: učnimi motnjami, vedenjskimi motnjami in motnjami govora (28).

Nedonošenčki zaradi prezgodnjega rojstva nimajo zalog vitamina E. Serumske koncentracije ostajajo kljub primernemu vnosu s hrano prenizke še v prvih mesecih življenja, kar je posledica slabšega vsrkavanja iz prebavil in hitre rasti. Pomanjkanje se kaže s slabokrvnostjo (hemolitična anemija zaradi okvare membrane eritrocita), mišično šibkostjo ter kreatinurijo. Priporočen dnevni vnos vitamina $\mathrm{E}$ pri nedonošenčku je $5-10 \mathrm{mg} / \mathrm{kg}$ telesne teže, fiziološke serumske vrednosti pa so med $0,8 \mathrm{mg} / \mathrm{dl}$ in $3,5 \mathrm{mg} /$ dl. Povečan odmerek (10 mg dnevno) dajemo nedonošenčkom $z$ retinopatijo in novorojenčkom, ki prejemajo EPO in/ali visoke odmerke železa (> $5 \mathrm{mg}$ / $\mathrm{kg} / \mathrm{dan}$ ) še nekaj tednov po odpustu iz bolnišnice (do 2. meseca korigirane starosti). Tocopherol praške pripravijo $v$ lekarni in jih ne smemo dajati hkrati s pripravki železa, saj vitamin E moti absorpcijo železa iz prebavil (35).

\section{Zaključek}

Vzroki anemije pri novorojenčku so različni in vselej odvisni tudi od otrokove nosečnostne starosti. Side- 
ropenična anemija v obdobju novorojenčka predstavlja tveganje za motnje v razvoju možganov, zato sta ključna zgodnja prepoznava in zdravljenje sideropenije. Pomanjkanje železa je pri donošenih novorojenčkih povezano s slabšim kognitivnim razvojem, pri nedonošenih pa s slabšim motoričnim razvojem.

$Z$ analizo celotne krvne slike ugotovimo standardne indekse eritrocitov, sodobni hematološki analizatorji pa omogočajo tudi določanje retikulocitov in nekaterih retikulocitnih kazalnikov, s katerimi lahko na neinvaziven način v osnovnem hemogramskem vzorcu pridobimo informacijo o trenutni razpoložljivosti železa v kostnem mozgu in ocenimo aktivnost eritropoeze.

\section{Literatura}

1. Ohls RK, Bishara N, Wong W, Glader B. Anemia in the Neonatal Period. In: Stevenson DK, Cohen RS, Sunshine P. Neonatology: Clinical Practice and Procedures. McGraw-Hill Education, 2015; 439-62.

2. Samokhvalov IM, Samokhvalova NI and Nishikawa S. Cell tracing shows the contribution of the yolk sac to adult haematopoiesis. Nature 2007; 446: 1056-61.

3. Rajić $\vee$, Jazbec J. Obravnava otroka z anemijo Slovenska pediatrija 2012; 19: 35-43.

4. Dessypris EN, Krantz SB. Erythropoietin: regulation of erythropoiesis and clinical use. Advances in pharmacology 1990; 21: 127-47.

5. Tavassoli M. Embryonic and fetal hemopoiesis: an overview. Blood cells 1991; 17: 269-81; discussion 82-6.

6. Dzierzak E, Philipsen S. Erythropoiesis: development and differentiation. Cold Spring Harbor perspectives in medicine 2013; 3(4): a011601.

7. Korenhauser Cerar L. Lijec enje anemije zbog nedonošenosti rekombinantnim humanim eritropoetinom (Treating anemia of prematurity with recombinant human erythropoietin. MA (thesis). Zagreb: University of Zagreb; 2000.

8. Boissel JP, Bunn HF. Erythropoietin structurefunction relationships. Progress in clinical and biological research 1990; 352: 227-32.

9. Lacombe C, Da Silva JL, Bruneval P, Casadevall N, Camilleri JP, Bariety J, et al. Erythropoietin: sites of synthesis and regulation of secretion. American journal of kidney diseases : the official journal of the National Kidney Foundation 1991; 18(4 Suppl 1): 14-9.

10. Higgs DR, Engel JD, Stamatoyannopoulos G. Thalassaemia. Lancet 2012; 379: 373-83.

11. Higgs DR. The molecular basis of alpha-t- halassemia. Cold Spring Harbor perspectives in medicine 2013; 3: a011718.

12. Schechter AN. Hemoglobin research and the origins of molecular medicine. Blood 2008; 112: 3927-38.

13. Sankaran VG, Orkin SH. The switch from fetal to adult hemoglobin. Cold Spring Harbor perspectives in medicine 2013; 3: a011643.

14. Košnik M, Mrevlje F, Štajer D et al. Interna medicina. 4 izdaja. Ljubljana: Literra picta, 2011.

15. Brugnara C. Iron deficiency and erythropoiesis: new diagnostic approaches. Clinical chemistry 2003; 49(10): 1573-8.

16. Preložnik Zupan I, Lenart K. Klinični pomen novih metod (količina hemoglobina $v$ retikulocitih in hipokromni eritrociti) za oceno pomanjkanja železa v telesu. Zdravniški vestnik 2004; 73: 499-502.

17. Orkin SH, Nathan DG, Ginsburg D et al. Nathan and Oski's Hematology of Infancy and Childhood. 7th ed. Philadelphia: Saunders Elsevier, 2008: 1770-4

18. Steiner LA, Gallagher PG. Erythrocyte disorders in the perinatal period. Seminars in perinatology 2007; 31(4): 254-61.

19. Arcara K, Tschudy M. The Harriet Lane Handbook. 19th ed. Philadelphia: Elsevier Mosby; 2012

20. Kliegman RM, Stanton BMD, St. Geme J, Schor NF. Nelson textbook of pediatrics. 20th ed. Philadelphia: Saunders Elsevier, 2016.

21. Christensen RD, Yaish HM, Henry E, Bennett ST. Red blood cell distribution width: reference intervals for neonates. The journal of maternal -fetal \& neonatal medicine 2015; 28: 883-8.

22. Kovačič R. Sintezni retikulocitni indeks kot pokazatelj aktivnosti kostnega mozga (magistrsko delo). Ljubljana: Univerza v Ljubljani; 2011.

23. Aher S, Malwatkar K, Kadam S. Neonatal anemia. Seminars in fetal \& neonatal medicine 2008; 13: 239-47.

24. Christensen RD, Henry E, Bennett ST, Yaish $H M$. Reference intervals for reticulocyte parameters of infants during their first 90 days after birth. Journal of perinatology 2016; 36: 61-6.

25. Lorenz L, Peter A, Arand J, Springer F, Poets CF, Franz AR. Reference Ranges of Reticulocyte Haemoglobin Content in Preterm and Term Infants: A Retrospective Analysis. Neonatology 2017; 111: 189-94.

26. Segel GB, Hirsh MG, Feig SA. Managing anemia in pediatric office practice: Part 1. Pediatrics in review 2002; 23: 75-84.

27. Segel GB, Hirsh MG, Feig SA. Managing anemia in a pediatric office practice: Part 2. PediatriCs in review 2002;23: 111-22.

28. Rao R, Georgieff MK. Iron in fetal and neonatal nutrition. Seminars in fetal \& neonatal medicine 2007; 12: 54-63.

29. Rao R, Georgieff MK. Iron therapy for preterm infants. Clinics in perinatology 2009; 36: $27-42$.

30. Powers JM, McCavit TL, Buchanan GR.

Management of iron deficiency anemia: a survey of pediatric hematology/oncology specialists. Pediatric blood \& cancer 2015; 62: 842-6.

31. Miksić M, Dukić Vuković T, Pogorevc R, Treiber $\mathrm{M}$. Treatment with erythropoietin in Neona- tology. Signa Vitae 2016; 11: 61-65.

32. De Alarcón PA, Werner EJ, Christensen RD. Neonatal Hematology: Pathogenesis, Diagnosis, and Management of Hematologic problems. 2nd ed. New York: Cambridge University Press. 2013.

33. Christensen RD, Rothstein G. Erythropoietin affects the maturation pattern of fetal G-CSF-responsive progenitors. American journal of hematology 1992; 39: 108-12.

34. Szczepanek-Parulska E, Hernik A, Ruchala $M$. Anemia in thyroid diseases. Polish archives of internal medicine 2017; 127: 352-60.

35. Arnon S, Regev RH, Bauer S, Shainkin-Kestenbaum R, Shiff Y, Bental Y, et al. Vitamin E levels during early iron supplementation in preterm infants. American journal of perinatology 2009; 26: 387-92.

doc. dr. Petja Fister, dr. med. (kontaktna oseba / contact person) Klinični oddelek za neonatologijo, Pediatrična klinika, Univerzitetni klinični center Ljubljana, Bohoričeva 20, 1000 Ljubljana, Slovenija e-naslov: petja.fister@kclj.si

Katerina Stojanov, dr. med.

Zdravstveni dom Krško, Krško, Slovenija

doc. dr. Barbara Faganel Kotnik, dr. med.

Klinični oddelek za hematologijo in onkologijo, Pediatrična klinika, Univerzitetni klinični center Ljubljana, Ljubljana, Slovenija

prispelo / received: 20. 7. 2020

sprejeto / accepted: 17. 8. 2020

Fister P, Stojanov K, Faganel Kotnik B. Laboratorijski kazalniki anemije pri novorojenčku. Slov Pediatr 2020; 27(4): 172-178. https://doi. org/10.38031/ slovpediatr-2020-4-02. 